\title{
“RUWAIBDA HADITH AND LEGAL PROVISIONS LEARNED FROM A CRITICAL ANALYSIS STUDY"
}

\author{
Jasim Mohammed Rashid Rashid
}

Assistant Professor Doctor; dr.jasmalrashd@uofallujah.edu.iq University Of Fallujah , Department Of Prophetic Hadith Sciences

\section{ABSTRACT:}

There is no doubt that understanding the texts of theAL Qur'an and the Sunnah is correct and one of the most important influences in preparing a Muslim's mind, thinking and misunderstanding. It has made the ummah divisions, parties and groups that move away and approach pure and pure Islam whenever their understanding is controlled by the rules of the AL Qur'an and Sunnah and a sound mind far from whims and hatred, and away from ignorance and hatred The ignorant and the hateful are the same in defaming Islam and distorting its image.

The hadith of the Holy Prophet, may ALLAH prayers and peace be upon him, in Al-Rawabda and the future foresight in it are important topics that need to be studied and scrutinized, because the Prophet, may ALLAH prayers and peace be upon him, reported on matters whose features have been revealed in our present time, and I did not find anyone who studied this topic in a careful, analytical, scientific study. To demonstrate the authenticity of the hadith due to its weakness, by examining the evidence that it came to make it possible to benefit from the legal rulings that it included to convert the Prophet's Sunnah from the texts preserved between the lines into our daily practical life as a control for our dishonor, a guide and a guide.

The nature of this research required that it be divided into three demands

The first requirement - the methods of hadith, its chain of narrators, and the reasons for it

The second requirement - the text adopted from the hadithThe third requirement - the legal provisions learned from it As for the first requirement, the chain of narrators, through studying this requirement carefully, it became clear to me that the hadith was transmitted by three of the Companions: Abu Huraira, AnasIbn Malik, AwfIbn Malik Al-Ashajai, may Allah be pleased with them all, and a group of narrators transmitted it from them, and in some of these methods some drawbacks and reasons, including the research And then I will study, research and scrutiny

As for the second requirement, it was in the text adopted from the hadith, which combines the different expressions of the hadith in different ways. It is his saying (the Messenger of Allah, may Allah prayers and peace be upon him. It was said: O Messenger of God, and who is Al-Rawaidah? He said: A fool speaks about common matters.

As for the third axis, the legal rulings learned from the hadith, this hadith is considered one of the future miracles of the Holy Prophet, may Allah prayers and peace be upon him, which were revealed by the days and years, because it describes our reality today and that it lives in it, may Allah bless him and grant him peace. Understanding texts and linking them to facts and events is not a real revelation, but rather an interpretation and diligence that can be wrong and correct and delude people that this understanding and interpretation is the revealed revelation, and it is the intention of Allah Almighty and His Messenger, may Allah prayers and peace be upon him. To denounce Islam and Muslims and bring out the confused image of Islam and Muslims in front of people and deceives that this is the Islam that Muhammad, may Allah prayers and peace be upon him and his companions, may Allah be pleased with them all, brought. This is a lie and a shame on Allah, His Messenger and Islam.

Keywords :

Ruwaibda hadith and, critical analysis study .

Article Received: 18 October 2020, Revised: 3 November 2020, Accepted: 24 December 2020

\section{INTRODUCTION}

Praise be to ALLAH, Lord of the worlds, and prayers and peace be upon our master Muhammad, his good family and his close companions, and those who followed them with charity until the Day of Judgment Either after

There is no doubt that understanding the texts of the AL Qur'an and the Sunnah is correct and one of the most important influences in preparing a Muslim's mind, thinking and misunderstanding. It has made the ummah divisions, parties and groups that move away and approach pure and pure Islam whenever their understanding is controlled by the rules of the AL Qur'an and Sunnah and a sound mind far from whims and hatred, and away from ignorance and hatred The ignorant and the hateful are the same in defaming Islam and distorting its image. 
The hadith of the Holy Prophet, may ALLAH prayers and peace be upon him, in Al-Rawabda and the future foresight in it are important topics that need to be studied and scrutinized, because the Prophet, may ALLAH prayers and peace be upon him, reported on matters whose features have been revealed in our present time, and I did not find anyone who studied this topic in a careful, analytical, scientific study. To show the authenticity of the hadith from its weakness, by stating the evidence that it came to enable us to benefit from the legal rulings that it included to convert the Prophet's Sunnah from the texts preserved between the lines into our daily practical life, controlling our dishonesty, a guide and a guide.

The nature of this research necessitated that it be divided into three demands

The first requirement - the methods of hadith, its chain of narrators, and the reasons for it.

The second requirement - the text adopted from the hadith

The third requirement - the legal provisions learned from it

As for the first requirement, the chain of narrators, through studying this requirement carefully, it became clear to me that the hadith was transmitted by three of the Companions: Abu Huraira, AnasIbn Malik, AwfIbn Malik Al-Ashajai, may ALLAH be pleased with them all, and a group of narrators transmitted it from them, and in some of these methods some drawbacks and reasons, including the research And then I will study, research and scrutinyAs for the second requirement, it was in the text adopted from the hadith, which combines the different expressions of the hadith in different ways. It is his saying (the Messenger of ALLAH, may ALLAH prayers and peace be upon him. It was said: O Messenger of ALLAH, and who is AlRawaidah? He said: A fool speaks about common matters.

As for the third axis, the legal rulings learned from the hadith, this hadith is considered one of the future miracles of the Holy Prophet, may ALLAH prayers and peace be upon him, which were revealed by the days and years, because it describes our reality today and that it lives in it, may ALLAH bless him and grant him peace. Understanding texts and linking them to facts and events is not a real revelation, but rather an interpretation and diligence that can be wrong and correct and delude people that this understanding and interpretation is the revealed revelation, and it is the intention of ALLAH Almighty and His Messenger, may ALLAH prayers and peace be upon him. To denounce Islam and Muslims and bring out the confused image of Islam and Muslims in front of people and deceives that this is the Islam that Muhammad, may ALLAH prayers and peace be upon him and his companions, may ALLAH be pleased with them all, brought. This is a lie and a shame on God, His Messenger and Islam,As for the conclusion, it contained the most important findings of the researchThe research relied on a group of sources and references, which were required by the nature of the researchIn conclusion, I ask ALLAH Almighty to return Islam to the reality of Muslims softly as it was revealed, and to fix the condition of our nation to the best of circumstances. He is the guardian of that and the one capable of it.

The first request is the evidence of the hadith

This hadith was received from different ways and from three of the Companions, namely $\mathrm{Abu}$ Hurairah, Anas Malik, and Awf Malik Al-Ashaji, may Allah be pleased with them all.

First: Abu Hurairah, may Allah be pleased with him.

This hadith was narrated through Abu Hurairah, may God be pleased with him, by a group of narrators, and they are as follows:

\section{Saeed Al-Maqbari}

A ruler said: Tell us Abu BakribnAbiShaybah, told us the son of Aaron over, told us Abdul Malik bin QudaamahAlbebb, Arafat, Arafat, Abguib, Abguib, cabled, Aviv, Aviv, Aviv, Aviv. 
This hadith was transmitted by this chain of transmission by Al-Hakim ${ }^{1}$ IbnMajah $^{2}$, Imam Ahmad ${ }^{3}$, and Al-Bayhaqi. ${ }^{4}$

\section{Statement of the narrators' status}

Abu Bakr bin AbiShaybah is $\left({ }^{5}\right)$ - Abu Bakr bin AbiShaybah al-Hafiz, without a peer, Abdullah bin Muhammad bin AbiShaybah Ibrahim bin Othman bin Khwasti al-Absi, their master Kufi, the owner of the Musnad and the compiler

Al-Ajali said: The trustworthy of Hafez. As well as Abu Zar'ah Al-Razi said. Abu Ubayd said: The hadeeth ended with four, and $\mathrm{Abu} B a k r$ bin AbiShaybah told them to him

And Salih bin Muhammad said: The most knowledgeable of the hadith and the reason for it is Ali bin Al-Madini, and Abu Bakr bin AbiShaybah memorized them for him when deliberating. On the authority of Abu Ubayd he said: The best of them was the book of Abu Bakr bin AbiShaybah. AlKhatib said: Abu Bakr was a master and a conservative. Class Musnad, provisions and interpretation. Al-Bukhari said: $\mathrm{He}$ died in Muharram in the year thirty-five and two hundred, may Allah Almighty have mercy on him. Several hadiths occurred to me from his dependents.

Yazid bin Harun ${ }^{6}$ is: Yazid bin Harun bin Zazhi Al-Hafiz Al-Qudwa Sheikh Al-Islam Abu Khaled

\footnotetext{
1 -Contested ruler 4 / 465-466.

2 - SunanIbnMajah Verifying Al-Arna`ut (Book of Seditions Hadith No. (4036) Chapter: Hardness of Time) (5/162.

3 - Musnad Ahmad - The World of Books (2/291.

4 - Al-Bayhaqi 8/313.

5 - - Tahdheeb al-Tahdheeb: 6/2 "1". Al-Tahdheeb approximation: 1/445 "589". The date of al-Bukhari alKabir: 2/365. The wound and the amendment: 5 / 737 . The balance of moderation: 2 / 490. The tongue of the balance: 7/268. Al-WafiDeaths: 17/442. March of the flags: $11 / 122$ and the footnote. Al-Thiqaat: $8 / 358$. AlHafiz ticket 2/16.

6 - Tahdheeb al-Kamal: 3/1544. Tahdheeb al-Tahdheeb: 11/366 "711". Rounding of the rounding: 2/372. The summary of Tahdheeb al-Kamal: 3/178. Al-Kashif: 3/287. The date of al-Bukhari al-Kabir: 8/368. The date of al-Bukhari al-Saghir: 2/307, 209. / 259. The date of alThiqaat: 481. Introduction to al-Fath: 453 . Translations of al-Adar: 4 / 225. Nassim al-Riyadh: 3 / 402. The date
}

Al-Salami, their master Al-Wasiti: He was born in the year eighteen and a hundred. Heard from Asim Al-Ahwal and Yahya bin

Saeed, Suleiman Al-Taymi, Al-Hariri, Daoud bin Abi Hind, IbnAoun, and many creatures. Narrated by Ahmad, Ibn al-Mudaini, Abu Khaithama and Abu Bakr bin AbiShaybah. Ibn al-Madini said: I have never seen more memorable than Yazid bin Harun, and Yahya bin Yahya said: More is more memorable than Wakea. Ahmed said Yazid was a master. Ziyad bin Ayyoub said: I have never seen anything more than a book. Ali bin Shuaib said: I heard Yazid say: I memorize twenty-four thousand hadiths, with no pride, and I memorize twenty thousand for the Levantines that I do not ask about. Ahmed said: Yazid had a jurisprudence. What was the smartest, I understand and understand him. Ahmad bin Sinan said: I did not see the best prayer from him, he did not stop praying, and on the authority of Asim bin Ali, he said: He used to increase the night and pray the morning with the ablution of darkness for forty years. Yahya bin AbiTalib said: "I heard from Yazid in Baghdad, and it was said in his council seventy thousand." AlAjali said: He increases the confidence of a worshiper who has proven very good prayer. Duha prays sixteen rak'ahs of good quality, and he was blind. IbnAbiShaybah said: We have not seen the best of Increases. Abu Hatim said: He increases the confidence of an imam who does not ask about someone like him.

Abd al-Malik bin Qudamah ${ }^{7}$ is Abd al-Malik bin Qudamah bin Ibrahim bin Muhammad bin Hatib alJamhi.

On the authority of Al-Muqbari, Amr bin Shuaib, his father, and a group. And on his authority Yazid bin Aaron, Ismail bin AbiUwais, Musa bin Ismail, and others.

of Asma al-Thiqaat: 1554. TabaqatibnSa'd: 6/384, 7/322, 356. History by IbnMa'in : 3 / 677. The Walk of the Flags 9/358 and the footnote. Authors' Dictionary: 13/238 and footnote. Diwan of Islam: Tel: 2199.

7 - Refinement of perfection in the names of men $(18 / 380$ History of Islam by Bashar 4/446 
IbnMa'in said: Good. Abu Hatim said: $\mathrm{He}$ is weak, not strong. Abu Dawud said: Abd al-Rahman used to praise him, and in his hadith he denounced it. Al-Daraqutni said: He leaves.

IbnHibban said: "He was sincere in the narration, except that he was one of those who made a mistake and increased his delusion until he brings something to the delusion and turns it away from its meaning and turns it away from its Sunnah. It is not permissible to invoke it when the trustworthy people did not agree" . 1

Ishaqibn al-Furat ${ }^{2}$ is Ishaq "bin Abi al-FuratBakr alMadani. It was narrated on the authority of Sa'id alMaqbari, and on his authority, Abd al-Malik bin Qudamah al-Jamie. Muslim Bin Qasim AlAndalusiIshaq bin Abi Al-Furat said: "Anonymous."

Al-Busiri said: This is a chain of narrators in which there is an article.

Manhattan said: Muslim bin Qasim said: IbnAbi AlFurat is unknown.

It came in the footnotes of the transcription from the author's saying: He mentioned it: "I mean Abd alGhani al-Maqdisi, in Bab al-Qaf, and he called it Qubisa, and an illusion in that.

Saeed Al-Maqbari ${ }^{3}$ is: Saeed bin AbiSaeedKaysan, the modern imam of trust, Abu Saeed al-Maqbari alMadani, the sire of BaniLaith: he heard his father, Abu Huraira, Abu Saeed, Saad bin AbiWaqas, Jabir bin Muta'im, Jabra, Ansa and Aisha

\footnotetext{
1 -The wounded $2 / 135$.

2 - The History of Baghdad, Editing by Bashar Awwad 6/172, Completing Tahdheeb Al-Kamal 2/108, AlZawaid, Paper 253.

3 -Tahdheeb al-Kamal: 1/312. Tahdheeb al-Tahdheeb: 2 / 432. The Tahdheeb al-Kamal: $1 / 192$. Summary of Tahdheeb al-Kamal: 1/245. Al-Kashif: 1/246. AlBukhari's Big Date: 2/332. Al-Bukhari's Little History: $1 / 276277,292,293,=294,295$. The wound and the correction: 3 / 567. The balance of moderation: 1 / 577 . The tongue of the balance: 2 / 336. TabaqatIbnSaad: 6/226, 320. Al-Wafi death: A13 No. 118 111. Fragments: 1/151. A score of the flags: 5/208. Al-Thiqaat: 4/144
}

Ahmed and IbnMa'in said nothing wrong with him. Ali, IbnSaad, Abu Zar'ah, and Jamaa said: He is trustworthy, and some of them say: He grew up and mingled four years before his death.

Al-Dhahabi said in al-Meezan: I do not think that someone took him from mixing.

And his hadith in the rest of the Sahih Abu Ubaid said: He died in the year twenty-five and one hundred. Six was said: It was said otherwise.

Through the foregoing, it became clear to us that this bond has two forms:

The first: Abd al-Malik bin Qudamah, the scholars spoke about it, and some of them trusted him as IbnMu'in, who Salih said about it. Al-Duri said: "I heard Yahya say: Abd al-Malik binQudamah alJamhi is trustworthy ${ }^{4} \mathrm{IbnShaheen}$ said: "On the authority of Yahya bin Maeen - Abd al-Malik bin Qudamah al-Jamhi is trustworthy" 5

Some of them were weak, such as IbnAbiHatim, who said that it was weak. Imam al-Dhahabi narrated it, and some of them hesitated about it. He said in his hadith the nakara of KabiDawood and Imam al-Bukhari.

IbnHibban said, "He was sincere in the narration, except that he is suffering from the obscenity of his mistake and his delusion so much that he brings something to the delusion, it is permissible to protest against him as he did not agree to it ${ }^{6}$

Valngrat came to him from the many and his illusion

The second problem: the hadith in the hadith, the chains of narration of IbnAbi al-Furat, which has been translated, and his name was mentioned in some of the isnads Muhammad ibn al-Furat, and in some of them the link between Muhammad ibnAbi al-Furat and between them and the hadith in the different isnads gave us a translation.

\footnotetext{
4 - Date of IbnMu'in 3/75 No. (297).

55 -History of the names of trustworthy "(157) No. (893).

6 - IbnHibban "Al-Majrouhin" 2/135:
} 
It was necessary for the man to be known from these isnads, and not to be called anonymous, and this is what was mentioned by some scholars who have documented him based on knowledge of his condition.

Sheikh Ahmad Shaker commented on that by saying (Ishaq bin Bakr bin Abi Al Furat Al Madani: translated in al-Tahdheeb and its branches under the name: "IshaqIbnAbi al-Furat, Bakr al-Madani," as if the author of al-Tahdheeb thought that "Abu alFurat" was called "Bakr".

This is because his name occurred in IbnMajah, in the chain of transmission of this hadith, "Ishaq bin Abi Al Furat" only, and I did not find him a translator other than al-Tahdheeb, but the author al-Tahdheeb himself, mentioned it correctly, in the translation of "Abd al-Malik bin Qudamah," he mentioned in his sheikhs: Ishaq bin Bakr bin Abi Al-Furat. Then this correctness is supported by that he will come with this name in another hadith in AlMusnad: 7913, and that Al-Sindi also transmitted it according to the correctness in IbnMajah's explanation, on the authority of Zaidat Al-Busiri, as will come in Al-Takhreeh, God willing. So what is in IbnMajahis: that he was attributed to his grandfather for short. This narrator said about him Al-Dhahabi and others: "Anonymous." But IbnHibban mentioned it in Al-Thiqaat, and AlHakim corrected it and Al-Dhahabi agreed with it. For some of them knew his personality and condition.) ${ }^{1}$

Despite all this, we will take with caution and say, as Sheikh Shuaib Al Arna ut said: (This is a weak chain of transmission for the weakness of Abd alMalik bin Qudamah and the ignorance of Ishaq bin Bakr bin Abi Al Furat).

B Abu Bakr Mohammed bin Jaafar cartographer: Tell us Ali bin ZaidLafraida, told us Abu YacoubHunaini, told us Abdul Malik bin
QudaamahJamhi from Ishaqibn al-Furat, Said ibnAbi Said Maqbari, from Abu Hurayrah .2

It was necessary for the man to be known from these isnads, and not to be called anonymous, and this is what was mentioned by some scholars who have documented him based on knowledge of his condition.

Sheikh Ahmad Shaker commented on that by saying (Ishaq bin Bakr bin Abi Al Furat Al Madani: translated in al-Tahdheeb and its branches under the name: "IshaqIbnAbi al-Furat, Bakr al-Madani," as if the author of al-Tahdheeb thought that "Abu alFurat" was called "Bakr".

This is because his name occurred in IbnMajah, in the chain of transmission of this hadith, "Ishaq bin Abi Al Furat" only, and I did not find him a translator other than al-Tahdheeb, but the author al-Tahdheeb himself, mentioned it correctly, in the translation of "Abd al-Malik bin Qudamah," he mentioned in his sheikhs: Ishaq bin Bakr bin Abi Al-Furat. Then this correctness is supported by that he will come with this name in another hadith in AlMusnad: 7913, and that Al-Sindi also transmitted it according to the correctness in IbnMajah's explanation, on the authority of Zaidat Al-Busiri, as will come in Al-Takhreeh, God willing. So what is in IbnMajah is: that he was attributed to his grandfather for short. This narrator said about him Al-Dhahabi and others: "Anonymous." But IbnHibban mentioned it in Al-Thiqaat, and AlHakim corrected it and Al-Dhahabi agreed with it. For some of them knew his personality and condition.) ${ }^{3}$

Despite all this, we will take with caution and say, as Sheikh Shuaib Al Arna ut said: (This is a weak chain of transmission for the weakness of Abd alMalik bin Qudamah and the ignorance of Ishaq bin Bakr bin Abi Al Furat). ${ }^{4}$ 
B Abu Bakr Mohammed bin Jaafar cartographer: Tell us Ali bin ZaidLafraida, told us Abu YacoubHunaini, told us Abdul Malik bin QudaamahJamhi from Ishaqibn al-Furat, Said ibnAbi Said Maqbari, from Abu Hurayrah .1

Al-Harith, Abdah bin AbiLababa and Taifa, and on his authority Abu Dawud Al-Tayalisi, Sareej bin AlNu'man, Yahya bin Saleh Al-Wahazi, Saeed bin Mansour, Abu Al-Rabeeh Al-Zahrani, Muhammad bin Jaafar Al-Warkani, many creatures, and his son Muhammad, and he was a sincere scholar who had a hadith and what is solid. As for Yahya bin Ma'in, he said: Not. Baqawi: And he once said: Weak, and he once said: His hadith is not that permissible, and Abu Dawud said: He is not cited, and Al-Nasa'i said: He is not strong: He died in the year sixtyeight in Medina.

2- Ibn al-Raceq, who is: Saeed bin Ubaid bin alSaraq al-Thaqafi, father of the civil race.

Narrated on the authority of: Ayyub bin Bashir alAnsari, his father Ubaid bin al-Sabaq, Muhammad ibnUsamaibnZayd, Abu Sa`id al-Khudri, and Abu Hurayrah

Narrated on him by: Ismail bin Muhammad bin Saad bin AbiWaqas, Suhail bin AbiSalih, Falih bin Suleiman, Muhammad bin Ishaq, Muhammad bin Muslim bin Shihab al-Zahri, and Yazid bin Zuhri.

Al-Nasa'i said: Trust. It was mentioned by IbnHibban in the book "Al-Thiqaat".

Narrated by Abu Dawood, Tirmidhi, and IbnMajah , This isnad is one of the strongest isnads and there is no problem in it, and it was his right to not relinquish the degree of validity without some of the article in the memorization of Flih and his hadith in

1 - Tahdheeb al-Kamal: 2 / 1106. Tahdheeb al-

Tahdheeb: 8/303 "551". Al-Tahdheeb Rounding: 2/114. Summation of Tahdheeb Al-Kamal: 2/341. Al-Kashif: 2/387. Al-Bukhari al-Kabir's Date: 7/133. Al-Bukhari alSaghir's Date: 2/176. Al-Jarrah and Al-Modification: 7 / 479. The Balance of Moderation: $3 / 365$ The date of Asmaa al-Thiqaat: 1142. Thiqaat: 7/324. Al-Mughni: 4969. Translations of the rabbis: $3 / 238$. TabaqatIbnSa'd: 5/285, 309, 7/341. Naseem al-Riyadh: 1/146, 2/326. Sir Flags: $7 / 351$. the rank of Hassan, as was stated by Sheikh Shuaib Al Arnaout

FalihYazid Bin Ayyad continued in the narration of $\mathrm{Na}$ im Bin Hammad on the authority of Saeed Bin Ubaid Bin Al-Sabaq said: I heard Abu Hurairah, may Allah be pleased with him, say.$^{2}$

In this way, all possibility will be removed from the narration of Falih, to follow Yazid bin Ayyadh to Falih, to follow up completely from the fact that in his memorization an article, and the hadeeth of Saeed bin Ubaid bin Al-Sabaq on the authority of Abu Hurairah, may ALLAH be pleased with him, is a true hadeeth.And with the hadith of Saeed bin AlSabaq Al-Saheeh, he raises the problems from the narration of Abdul-Malik bin Qudma, and the hadith is authentic because Saeed bin Al-Sabaq followed Saeed Al-Maqbari, a complete follow-up on the authority of Abu Huraira, so the hadith of Abu Hurairah is a true hadith ${ }^{3}$

The talk received from Said Maqbari by his father as MEMRI forward ruler of the two roads, he said told us Mohammed bin Ibrahim Aharaz Abu Talib bin Gillan, Baqrata it is time, he said: Tell us Abu Bakr Mohammed bin Abdullah bin Ibrahim AlShafi'i, read it in the zero year four and fifty three hundred, he said: Tell us Musa ibnSahlibn many means: Aloa, he said: Tell us more than the son of Aaron, said: Tell us Abdul Malik bin Qudaamah, for Maqbari, from his father, from Abu Hurayrah ${ }^{4}$

The governor also Imam told us Abu Abbas Mohammed bin Ahmed MahaboubiBmro, Tna Said bin Masoud, forebode Yazid bin Harun, Abdul Malik bin forebode QudamahJamhi from IshaqibnBakribn al-Furat, Said ibnAbi Said Maqbari, from his father, from Abu Hurayrah Imam al-Hakim said: This hadith is a sound chain of transmission, and he did not narrate it. ${ }^{5}$

said another way: Tell us Ismail Abu Bakr bin Muhammad bin Ismail al-Faqih irrigators, Tna Abu

\footnotetext{
2 -Naeem Bin Hammad The Book of Seditions (1470).

3 - Al Mustadrak Hadith No. (8439) 4/512

4 -Al Mustadrak Hadith No. (8438) 4/512.

5 -Al Mustadrak Hadith No. (8438) 4/512.
} 
Bakribn al-Faraj Blue, TnaHajjaj bin Mohammed, Tna Abdul Malik bin QudaamahJamhi, Isaac Ben-a

AbiBakr, on the authority of Saeed bin AbiSaeed, on the authority of his father, on the authority of Abu Hurairah, may ALLAH be pleased with him, on the authority of the Prophet, may ALLAH prayers and peace be upon him, that he said: "People will come for years and drive the hadith and said: IbnQudama said: Yahya bin Saeed AlAnsari told me, on the authority of Al-Maqbari, He said: "And immorality becomes common in it." This hadith has a sound chain of narration, but it was not narrated. And it is from the hadeeth of Yahya bin Saeed Al-Ansari, on the cemetery, very strange ${ }^{1}$

The hadith has two witnesses, through Anasibn Malik, and from Malik ibnAwf al-Ashaja, may ALLAH be pleased with him. As for Anas, it comes:

A, Imam Ahmad said: Othman bin Muhammad bin AbiShaybah told us, Abu Abd al-Rahman said and I heard him from, Othman, he said: Abdullah bin Idris told me, on the authority of Muhammad bin Ishaq, on the authority of Abdullah bin Dinar, he said: I heard Anas

B) Imam Ahmad also said: Uthman bin Muhammad bin AbiShaybah told us, Abu Abd alRahman said and I heard him from, Uthman, he said: Abdullah bin Idris told me, on the authority of Muhammad bin Ishaq, on the authority of Abdullah bin Dinar, he said: I heard Anas

C - Abd al-Razzaq, on the authority of Muammar, on the authority of Sa idibnAbd al-Rahman alJahshi, on the authority of Abd Allah ibn Dinar, he said: Narrated by Marfa

As for the road to Auf bin Malik, as follows:

Abu Kuraib Muhammad ibn al-'Ala told us: "YunusIbnBakir told us, on the authority of Muhammad ibnAbihaq on the authority of Abraham.

Ahmad ibn al-Mualla al-Dimashqi and alHusaynibn al-Hasan said to us Hisham bin Ammar, Thana Muslimah bin Ali, on the authority

1 -Al-Mustadrak Hadith No. (5864) 4/557. of Ibrahim bin AbiAbla, on the authority of his father, on the authority of Awf bin Malik.

:Trustworthy, and IbnMu'in trusted him, and Abd al-Rahman bin Mahdi used to praise him, and say: "Malik used to talk about him, and in his speech there is a denunciation." Al-Bukhari said in the small history: "He heard from him

IbnAbiUwais, knows and denies. ${ }^{2}$ IbnAbd al-Barr said:" Civilian, trustworthy, honorable, "so he is on concealment - at least - and his hadith is no less than the degree of Hassan. And the hadeeth in Jami alMasanid, on the authority of Abu Bakr bin AbiShaybah, on YazidIbnHarun - Sheikh Ahmad here - with this chain of transmission, similar to it.

Al-Dhahabi said in Al-Kashef: Anonymous, and it was said: Denied. IbnHibban mentioned it in AlThiqaat. "It is astonishing that Al-Dhahabi says this about it in Al-Kashef, then he does not mention it at all in the balance of moderation !! And it is even stranger than that the ruler agrees to correct his hadith. Abu Bakr bin AbiShaybah and they were there, so he shortened the lineage of Ishaq and attributed it to his grandfather, and he abbreviated it, he said: Munad, so he made it on the authority of Sa id al-Maqbari on the authority of Abu Hurairah, without mentioning "on the authority of his father." Al-Hakim narrated it in Al-Mustadrak, through Sa id bin Masoud, on the authority of Yazid bin Harun. He said: "This is a hadith with a true chain of transmission, and they did not produce it." And the name of this narrator fell on Al-Mustadrak, "Ishaq bin Bakr bin Al-Furat" - by deleting the word "my father", and it seems that it is a mistake of a typist or typist. And there is another authentic chain of narration on the authority of Falih, on the authority of Saeed bin Ubaid bin Al-Sabaq, on the authority of Abu Huraira, with a chain of transmission narrating it. Then he has an authentic witness from the hadith of Anas, which will come in the Musnad, meaning, with two authentic isnads) ${ }^{3}$

\footnotetext{
2 -The Weakness of the Little Bukhari 87.

3 - Musnad of Ahmad T. Shaker (8/320 Hadith No. 13331 \& 13333).
} 
Thus, there remains no doubt the veracity of the conversation.

\section{The second topic: The approved text}

After that we proved the modern health, I will adopt the most complete texts and widely a novel Mustadrak, said Imam al-Hakim: (Tell us Abu Abbas Mohammed bin Ahmed MahaboubiBmro, Tna Said bin Masoud, forebode Yazid bin Harun, Abdul Malik bin forebode QudamahJamhi from IshaqibnBakribn al-Furat, said ibnAbi said Maqbari, from his father, from Abu Hurayrah, may Allah be pleased with him, the Prophet peace be upon him, said: «come on people years stumps believe the liar, and lying where sincere, in which he and entrusted the traitor, and betray the Secretary And he speaks in them the ar-ruwaida.

Years before the Hour of deception in which the truthful lies and the liar is true, and the trustee is betrayed in it, the traitor is trusted and the traitor speaks about it.) ${ }^{\mathrm{i}}$

\section{The third requirement : Legal provisions learned from the hadith}

Ibn al-Atheer said: "Al-Ruwaibda: Minimize the restless. He is the helpless who has crouched from the sublime of matters and has resigned from their request. The increase of the $T$ is for exaggeration. And the vile and despicable trifle" ii

ALLAH prayers and peace be upon him: "Years before the hour of deceit, the liar is believed in them, the truthful lies about them, the trustworthy is betrayed in them, the traitor is trusted, and al-Rawabidha speaks about them."

Abu Ubaid said: "He is a vile, vile man who speaks in public matters."

And it was narrated on the authority of Umar ibn al-Khattab, may ALLAH be pleased with him, that he said: "I have learned when people perish: If jurisprudence comes from the young, the old will be difficult for him, and if the jurisprudence comes from the elder, the young follow him, so guide him.

Abdullah bin Masoud said: People are still well as long as they take knowledge from their elders, so if they take it from their lesser and evil ones. Perished.

And the scholars discussed what Omar wanted with the young: As for Abdullah bin Mubarak; He said: "Al-Asghar: They are the people of innovation."

Abu Bakr bin Thabit Al-Khatib Al-Hafez said: "He only wanted him to be young, and in this he delegated education at a young age, like Omar also said: Be aware before you become blackened, that is, if you do not learn, you will prevail, you will be ashamed of education, so you took knowledge from your youth."

As for the judge, he said: "It is possible that the meaning of al-Asghar is: $\mathrm{He}$ who has no knowledge, and Umar ibn al-Khattab used to consult the young, and the readers were the owners of his advice, whether as they were or when they were young, and it is possible that the minor wants someone who has no destiny or condition, and that is only By rejecting religion and chivalry, as for the one who adheres to them, he must elevate his matter and magnify his worth. It was narrated on the authority of MaAkhool that he said: "The mob understands the corruption of the world, and the lesser understands the corruption of religion."

Al-Fryabi said: "When Sufyan Al-Thawri saw these Nabat writing, his face would change! I said to him: O Abu Abdullah! Do I see you if you see these people writing knowledge, it will get stronger for you ?! He said: Knowledge was among the Arabs and among the masters of the people. These meaning: Nabat and lowland - changed religion. "

Sufyan said: "They sought refuge in ALLAH from the evil of the temptation of the world, and from the evil of the trial of the ignorant worshiper; 
Wahb bin Munabbih said: "Collecting money and swearing the sultan does not remain one of the good deeds of a person except as two hungry wolves keep falling into a litter in which there are sheep, and then they roost until they became."

Sufyan Al-Thawri said: "It was the choice of the people and their honorable ones who rise to these princes, ordering and ending them, and others were obligated to their homes, so he did not benefit from them and did not remember, and then we remained until those who came to them became the evil of the people, and those who stayed in their homes became the people's choice."

Muhammad bin Sahnoun said: "Some scholars had a brother who came to the judge and the governor at night, and greeted them, and he informed him of that, so he wrote to him: As for after, whoever iii

He said Beji: is likely to be small fry from no knowledge of him, said: It was the age of consulting the young, and readers (the owners) consulted Khola and young men said, and are likely to want Balosagr of not as much as it is not the case, and then only to renounce religion and virility As for the one who adheres to them, he must elevate his matter and magnify his destiny.

It illustrates this interpretation of what was narrated by IbnWahab bond lump from al-Hasan said: worker unaware Calcair on non-road, and the worker are unaware of what corrupts more than fit, seek those things applied science (does not hurt to leave) worship, and seek to worship an application (does not hurt to leave ) flag, the folk asked for worship and left the flag until they went out Bociafhm on the nation of Muhammad peace be upon him, even if they asked the flag did not show them what they did

He said in the end: years of deception. That is, it has more rain, and the rent decreases, so that is its deception. Because it feeds them fertile with rain, then lags.
And it was said: The deception of little rain is one of the deceptions of the saliva if it dries up. ${ }^{1}$

And it was said that its meaning is: that a slave woman gives birth to kings, so that she will be a slave of the whole of his flock, and he is her master and the master of others from his flock. ${ }^{2}$

And it was said that it means: it spoils the condition of people, so that the mothers of the children are sold more often at the end of time, and it becomes more frequent in the hands of the buyers, until her son buys them and he does not know. ${ }^{3}$

And the correct one in the meaning of Baal: that he is the owner or the master, so it is in the meaning of her Lord, according to what was mentioned ${ }^{4}$

It is known that if the heads become fools, and the kings are according to what was mentioned of the case, the conditions and insults are reversed, and every door is opened for evil, and the hour is approaching, so then the liar is believed, the truthful lies, betrayed the trustworthy, the hypocritical traitor is trusted, the ignorant fool speaks, the virtuous world is silent, and executed Knowledge entirely, and taking its people out of the wilderness, as is proven in the authentic hadiths and clear and explicit texts.$^{5}$

On the authority of Auf bin Malik, may ALLAH be pleased with him; He said: The Messenger of ALLAH, may ALLAH prayers and peace be upon him, said: "There will be years of deception in front of the antichrist, in which there is a lot of rain, less sprouts in them, the truthful lies about them, the liar is believed in them, and the traitor is trusted, and the trustworthy is betrayed in them,

\footnotetext{
1-Al Mustadrak Hadith No. (8439) 4/512.

2 - Al Mustadrak Hadith No. (8439) 4/512The Weakness of the Little Bukhari 87.

3 - Accidents and Heresies / 79.

4 - Musnad of Ahmad T. Shaker (8/320 Hadith No. 13331 \& 13333)Al-Mustadrak Hadith No. (5864) 4/557Al Mustadrak Hadith No. (8438) 4/512.

5 - Al Mustadrak Hadith No. (8439) 4/512Falih Yazid Bin Ayyad continued in the narration of Na im Bin Hammad on the authority of Saeed Bin Ubaid Bin AlSabaq said: I heard Abu Hurairah, may Allah be pleased with him, say ().
} 
and Al-Ruwabida speaks in them." It was said: O Messenger of ALLAH! What is Rweibda? He said: "He who does not care for him."

Narrated by al-Tabarani with isnads. Al-Haythami said: "In the best of it is IbnIshaq, who is a medal, and the rest of his men are trustworthy" 1

Think about the creation, and do not think about ALLAH, "for the idea of the Lord ignites doubt in the heart.

And he said: And know, may ALLAH have mercy on you, that the scholars still rejected the saying of the Jahmiyya, until it was in the Khilafah of the Bani So-and-so. Al-Ruwaibida spoke about the matter of the common people, and challenged the effects of the Messenger of ALLAH - may ALLAH bless him and grant him peace - and they took analogy and opinion, and disbelieved those who disagreed with them, so he entered into their ignorant saying And the foolish one, and the one who has no knowledge, until they disbelieved from where they do not know, so the ummah perished from faces, disbelieved on faces, and became deceitful on faces, and strayed from faces, and it dispersed and innovated from faces, except for those who are proven to the words of the Messenger of ALLAH - may ALLAH bless him and grant him peace -, And he commanded and commanded his companions, and none of them made a mistake, and he did not overlook their matter, and expanded it as much as they could, and he did not desire according to their method and doctrine. And blessings - 2

The Messenger, may ALLAH prayers and peace be upon him, told us that the standards by which men are evaluated are disturbed before the Hour begins, so he accepts the telling of a lie and is true, responds to the truthful his news, and entrusts the traitors with money and honor, betray the trustees and accuse them, and the trivial men speak about issues that concern the common

1 - In this way, all possibility will be removed from the narration of Falih, to follow Yazid bin Ayyadh to Falih, to follow up completely from the fact that in his memorization an article, and the hadeeth of Saeed bin Ubaid bin Al-Sabaq on the authority of Abu Hurairah, may God be pleased with him, is a true hadeeth. 2 . people, so they do not present Except for crude opinions, and they are only guided to perverted matters. Imam Ahmad, IbnMajah, and the ruler reported on the authority of Abu Hurairah, who said: The Messenger of ALLAH, may ALLAH prayers and peace be upon him, said: "People will come upon years of deceit, in which the liar will be believed, the truthful will lie, and the traitor will be trusted and betrayed. It contains Al-Amin, and it is pronounced Al-Ruwaida. It was said: What is al-Ruwaibda. "He said:" The insignificant man speaks about the common cause"

And whoever contemplates the conditions of our world today finds that we are living in this age that the Messenger, may ALLAH prayers and peace be upon him, told about. The lie is among the infidels and polytheists who own news agencies and broadcasters and those on their way who believe, and the people of truth and justice lie, and the Islamic nation puts its money in the hands of unbelieving traitors, and they are entrusted with it. That, and Muslims betray and do not trust anything of that. He spoke about the affairs of the world, trivial men, and led him by a reckless leadership that was about to destroy all of humanity.

\section{REFERENCE}

[2] Ibrahim bin Musa bin Muhammad AlLakhmi Al-Gharnati, the famous AlShatby (deceased: 790 AH), Dr. Muhammad bin Abdul Rahman AlShuqair: Dr. Saad bin Abdullah Al Hamid: Dr. Hisham bin Ismail Al-Sini, Ibn Al-Jawzi House for Publishing and Distribution, Kingdom of Saudi Arabia, First Edition, 1429 AH - 2008 AD.

[3] Complete the refinement of perfection in men's names

[4] Maghalatai bin Qilij bin Abdullah AlBakri, the Egyptian Al-Hakri Al-Hanafi, Abu Abdullah, Ala Al-Din (deceased: 762 A.H.) 
[5] T: Abu Abd al-Rahman Adel bin Muhammad - Abu Muhammad Osama bin Ibrahim, Al-Farouq Modern Printing and Publishing, First Edition, $1422 \mathrm{AH}$ 2001 AD.beginning and end

[6] Abu al-Fida Ismail bin Omar bin Kathir al-Qurashi al-Basri then al-Dimashqi (deceased: $774 \mathrm{AH}$ )

[7] T: Ali Sherry, House of Revival of Arab Heritage, First Edition 1408 AH - 1988 AD History of trusted names

[8] Abu Hafs Omar bin Ahmed bin Othman bin Ahmed bin Muhammad bin Ayoub bin Azdad al-Baghdadi, known as IbnShaheen (deceased: $385 \mathrm{AH}$ ), T: Subhi al-Samarrai, The Salafist House Kuwait, i: the first, 1404 - 1984

[9] History of IbnMu in (Al-Douri novel)

[10] Abu ZakariaYahya bin Ma'in bin Aun bin Ziyad bin Bastam bin Abdul Rahman Al-Marri loyalty, Al-Baghdadi (deceased: 233 AH), d: Dr. Ahmad Muhammad NurSaif, Center for Scientific Research and the Revival of Islamic Heritage - Makkah AlMukarramah

[11] History of Baghdad

[12] Abu Bakr Ahmad bin Ali bin Thabit bin Ahmed bin Mahdi Al-Khatib AlBaghdadi (deceased: $463 \mathrm{AH}$ )

[13] T: Dr. Bashar AwadMaarouf, Dar Al Gharb Al Islami - Beirut, First Edition, 1422 AH - 2002 AD

[14] big history

[15] Muhammad bin Ismail bin Ibrahim bin al-Mughira al-Bukhari, Abu Abdullah (deceased: $256 \mathrm{AH}$ ), ed: The Ottoman Knowledge Department, Hyderabad Deccan, printed under the supervision of: Muhammad Abd al-Muayed Khan

[16] Arrangement of the five-year-olds

[17] Yahya (MurshidBillah) bin Al Hussein (Al Muwaffaq) bin Ismail bin Zaid Al Hasani Al Shajari Al Jarjani (died 499 $\mathrm{AH})$, ranks: Judge Muhyiddin
Muhammad bin Ahmad Al Qurashi Al Abashmi (died: $610 \mathrm{AH}$ )

[18] T: Muhammad Hassan Muhammad Hassan Ismail, Dar al-Kutub al-Ilmiyya, Beirut - Lebanon, first edition, $1422 \mathrm{AH}$ - 2001 AD

[19] Shams al-Din Abu Abdullah Muhammad bin Ahmad bin Othman bin Qaimaz alDhahabi (deceased: 748 AH), Dar AlKutub Al-Ilmiyya Beirut-Lebanon, First Edition, 1419 AH-1998 AD.

[21] Abu al-Fadl Ahmad bin Ali bin Muhammad bin Ahmed bin Hajar alAsqalani (deceased: $852 \mathrm{AH}), \quad \mathrm{T}$ : Muhammad Awamah

[22] Dar Al-Rashid - Syria, First Edition, 1406 - 1986 Refinement of refinement

Abu al-Fadl Ahmad bin Ali bin Muhammad bin Ahmad bin Hajar alAsqalani (deceased: $852 \mathrm{AH}$ ), Department of Regular Knowledge Press, India, I: First Edition, 1326 AH

Refine perfection in men's names

Yusuf bin Abd al-Rahman bin Yusuf, Abu al-Hajjaj, Jamal al-Din Ibn al-Zaki Abu Muhammad al-Qudai al-Kalbi alMazzi (deceased: 742 AH), T.: Dr. Bashar AwadMaarouf, The Resala Foundation - Beirut, First Edition, 14001980

[26] The Great Mosque - Sunan al-Tirmidhi

[27] Muhammad bin Isa bin Surah bin Musa bin al-Dhahak, al-Tirmidhi, Abu Issa (deceased: $279 \mathrm{AH}$ )

[28] T: Bashar AwadMaarouf, Dar Al Gharb Al Islami - Beirut: 1998 AD

[29] Wound and modification

[30] Abu Muhammad Abd al-Rahman bin Muhammad bin Idris bin al-Mundhir alTamimi, al-Hanzali, al-RaziibnAbiHatim (deceased: $327 \mathrm{AH}$ ), edition of the Ottoman Council of Knowledge Hyderabad Deccan - India, Arab Heritage Revival House - Beirut

[31] I: First, 1271 AH 1952 CE 
[32] $\square$ Collecting interest from the collector of assets and accumulator al-Zawaid

[33] Muhammad bin Muhammad bin Suleiman bin al-Fassi bin Taher al-Sousi al-Radwani al-Maghribi al-Maliki (deceased: $1094 \mathrm{AH}$ )

[34] T: Abu Ali Suleiman bin Dari'a, IbnKathir Library, Kuwait - Dar IbnHazm, Beirut, First Edition, 1418 AH - 1998 AD

[35] Accidents and fads

[36] Muhammad bin al-Walid bin Muhammad bin Khalaf al-Qurashi alFahri al-Andalusi, Abu Bakr alTartoushi al-Maliki (died: 520 AH), T.: Ali bin Hassan al-Halabi, Dar Ibn alJawzi, third edition, 1419 AH - 1998 CE

[37] Abstract gilding refinement of perfection in the names of men

[38] Ahmed bin Abdullah bin Abi al-Khair bin Abdul-Alim al-Khazraji al-Ansari alSaadi al-Yemeni, Safi al-Din (deceased: after 923 AH), Tel: Abd al-Fattah Abu Ghuddah, Islamic Publications Office / Dar Al-Bashaer - Aleppo / BeirutI: The Fifth, 1416 AH

[39] Diwan of Islam

[40] Shams al-Din Abu al-Maali Muhammad bin Abd al-Rahman bin al-Ghazi (died: 1167 AH), T.: Syed Kesrawi Hassan, Dar al-Kutub al-Ulmiyyah, Beirut Lebanon, First Edition, 1411 AH - 1990

[41] SunanIbnMajah

[42] IbnMajah Abu Abdullah Muhammad bin Yazid al-Qazwini, and Majah, his father's name Yazid (deceased: $273 \mathrm{AH}$ )

[43] T: Muhammad FuadAbd al-Baqi, House of Revival of Arab Books - Faisal Issa al-Babi al-Halabi

[44] Shams al-Din Abu Abdullah Muhammad bin Ahmad bin Othman bin Qaimaz alDhahabi (deceased: 748 AH), T.: A group of investigators under the supervision of Sheikh Shuaib AlArnaout, Al-Risala Foundation, Third Edition, 1405 AH / 1985 AD gold nuggets in gold news

[46] Abd al-Hayy bin Ahmad bin Muhammad ibn al-Imad al-Akry al-Hanbali, Abu alFalah (deceased: 1089 AH).

Muhammad bin Ismail bin Ibrahim bin al-Mughira al-Bukhari, Abu Abdullah (deceased: 256 AH), T: Mahmoud Ibrahim Zayed

[48] House of Consciousness - Aleppo, First Edition, $1396 \mathrm{AH}$

[49] major classes

Abu Abdullah Muhammad bin Saad bin Manea al-Hashemi al-Walaa, al-Basri, al-Baghdadi, known as IbnSaad (died: $230 \mathrm{AH})$

[51] T: Muhammad Abd al-Qadir Atta, Dar al-Kutub al-Ilmiyya - Beirut, First Edition, 1410 AH - 1990 AD

[52] $\square$ The precious contract in explaining the hadiths of the fundamentals of religion

[53] Hussein bin Ghannam (or IbnAbiBakr bin Ghannam) Najdi Al-Ahsa Al-Maliki (died: $1225 \mathrm{AH}$ ), indexed by the King Fahd National Library, First Edition 1423 AH / 2003 AD, T: Muhammad bin Abdullah Al-Habdan

[54] Al-Kashef to know who has a narration in the Six Books

[55] Shams al-Din Abu Abdullah Muhammad bin Ahmad bin Othman bin Qaimaz alDhahabi (deceased: 748 AH), T.: Muhammad Awamah Ahmad Muhammad Nimr al-Khatib, Dar alQiblah for Islamic Culture - The Foundation for the Sciences of the Qur'an, Jeddah, First Edition, 1413 AH 1992 CE

[56] The Book of Seditions

[57] Abu Abdullah Naim bin Hammad bin Muawiya bin Al-Harith Al-Khuzai AlMarwazi (died: 228 AH), T: Samir Amin Al-Zuhairi, Al-Tawhid Library - Cairo, First Edition, 1412

[58] Libra 
[59] Abu al-Fadl Ahmad bin Ali bin Muhammad bin Ahmad bin Hajar alAsqalani (deceased: 852 AH), T.: The Regular Identifier Department - India, Al-Alamy Foundation for Publications Beirut - Lebanon, Second Edition, 1390 AH / 1971 AD

[60] The wounded, the modern, the weak, and the neglected

[61] Muhammad bin Hibban bin Ahmed bin Habban bin Muadh bin Mu'abd, alTamimi, Abu Hatim, al-Darami, al-Basti (deceased: 354 AH), T: Mahmoud Ibrahim Zayed, Dar al-Awa'i - Aleppo, First: 1396 AH.

[62] But on the correct one

[63] Abu Abdullah al-Hakim Muhammad bin Abdullah bin Muhammad bin Hamdawiya bin Na'im bin al-Hakam alDhabi al-Tahmani al-Nisaburi, known as Ibn al-Sale (deceased: $405 \mathrm{AH}$ ), Tel: Mustafa Abdul Qadir Atta, Dar al-Kutub al-Ilmiyya - Beirut, ed: the first, 1411 1990

[64] Musnad of Imam Ahmad bin Hanbal

[65] Abu Abdullah Ahmad bin Muhammad bin Hanbal bin Hilal bin Asad alShaybani (deceased: 241 AH), T.: Shuaib al-Arnaout - Adel Murshid, and others, supervised by: Dr. Abdullah bin Abdul Mohsen al-Turki, Foundation for the message, First Edition, 1421 AH 2001 AD

[66] Noble morals, their sublime and praiseworthy ways

[67] Abu Bakr Muhammad bin Jaafar bin Muhammad bin Sahl bin Shaker alKhariti al-Samaritan (died: 327 AH), T.: Ayman Abdel-Jaber Al-Buhairi, Dar AlAfaq Al-Arabiya, Cairo, First Edition, 1419 AH - 1999 AD

[68] Singer in the weak

[69] Shams al-Din Abu Abdullah Muhammad bin Ahmad bin Othman bin Qaimaz alDhahabi (deceased: 748 AH), T: Dr. Nur al-Din Ater
[70] glossary of authors

[71] Omar bin Rida bin Muhammad Ragheb bin Abdul Ghani as the case of Damascus (deceased: 1408 AH), Muthanna Library - Beirut, Arab Heritage Revival House, Beirut

[72] Knowing the trustworthy men of scholars and hadiths, and the weak, and mentioning their doctrines and news

Abu Al-Hasan Ahmad bin Abdullah bin Saleh Al-Ajli Al-Kufi (deceased: 261 AH), T: Abdul-Alim Abdul-Azim AlBastawi, Al-Dar Library - Medina Saudi Arabia, First Edition, 1405 - 1985

$\square$ The balance of moderation in criticism of men

[75] Shams al-Din Abu Abdullah Muhammad bin Ahmed bin Othman bin Qaimaz alDhahabi (deceased: $748 \mathrm{AH}$ )

[76] T: Ali Muhammad Al-Bejaoui, Dar Al Marifa for Printing and Publishing, Beirut - Lebanon, First Edition, 1382 AH - 1963 AD

[77] $\square$ Resources of Imam Al-Bayhaqi in his book Al-Sunan Al-Kubra

[78] Najm Abdul RahmanKhalaf, Islamic University of Madinah, D: Year 18, Issues 71, Rajab 72 - Dhu al-Hijjah 1406 $\mathrm{AH}$

[79] Encyclopedia of the positions of the predecessors in belief, methodology and education

[80] Abu Sahl Muhammad IbnAbd alRahman al-Maghrawi, Islamic Library for Publishing and Distribution, Cairo Egypt, Nobles Book, Marrakech Morocco, Ed .: First

[81] Adequate mortality

[82] Salah al-Din Khalil bin Aybak bin Abdullah al-Safadi (died: 764 AH), T: Ahmad al-Arnaout and Turki Mustafa

[83] House of Revival of Heritage - Beirut, year of publication: $1420 \mathrm{AH}$ - $2000 \mathrm{AD}$ 
